receptor complexes. Endocrinology 108:720

9. Friedman WF 1972 The intrinsic physiologic properties of the developing heart. Progr Cardiovasc Dis 15:84

10. Harris WH, Van Petten GR 1979 Development of cardiovascular responses to noradrenaline, adrenaline, normetanephrine, and metanephrine in the unanesthetized fetus. Can J Physiol Pharmacol 57:242

11. Hatjis CG, McLaughlin MK 1982 Identification and ontogenesis of betaadrenergic receptors in fetal and neonatal rabbit myocardium. J Dev Physiol $4: 327$

12. Hatjis CG $1984 \beta$-adrenergic receptor ( $\beta$-AR) interaction with guanine mucleotides $(\mathrm{GN})$ in fetal rabbit myocardial membranes. Biol Neonate, 46:254

13. Hegstrand LR, Minneman KP, Molinoff PB 1979 Multiple effects of guanosine triphosphate on beta adrenergic receptors and adenylate cyclase activity in rat heart, lung, and brain. J Pharmacol Exp Ther 210:215

14. Jones LR, Besch HR, Fleming JW, McConnaughey MM, Watanabe AM 1979 Separation of vesicles of cardiac sarcolemma from vesicles of cardiac sarcoplasmic reticulum. J Biol Chem 254:430

15. Kaumann AJ, Birnbaumer L 1974 Studies on receptor-mediated activation of adenylyl cyclases. J Biol Chem 249:7874

16. Kohrman AF 1973 Patterns of development of adenyl cyclase activity and norepinephrine responsiveness in the rat. Pediatr Res 7:575

17. Lands AM, Arnold A, McAuliff JP, Luduena FP, Brown TG 1967 Differentiation of receptor systems activated by sympathomimetric amines. Nature 214:597

18. Levy MN, Martin PJ 1979 Neural control of the heart. section 2. In Berne RM (ed) Handbook of Physiology, vol I, Sect 2. American Physiological Society, Bethesda, MD, p. 581

19. Minneman KP, Hegstrand LR, Molinoff PB 1979 The pharmacological specificity of beta- 1 and beta- 2 adrenergic receptors in rat heart and lung in vitro. Mol Pharmacol 16:21
20. Polson JB, Goldberg ND, Shideman FE 1977 Norepinephrine and isoproterenol induced changes in cardiac contractility and cyclic adenosine $3^{\prime}, 5^{\prime}$ monophosphate levels during early development of the embryonic chick. J Pharmacol Exp Ther 200:630

21. Rudolph AM, Heymann MA 1974 Fetal and neonatal circulation and respiration. Annu Rev Physiol 36:187

22. Salomon Y, Londos C, Rodbell M 1974 A highly sensitive adenylate cyclase assay. Anal Biochem 58:541

23. Schumacher WA Sheppard JR, Mirkin BL 1982 Biological maturation and beta-adrenergic effectors: pre- and postnatal development of the adenylate cyclase system in the rabbit heart. J Pharmacol Exp Ther 223:587

24. Snyder FF, Drummond GI 1978 Activation and stabilization of cardiac adenylate cyclase by GTP analog and fluoride. Arch Biochem Biophys 185:116

25. Spiegel AM, Downs RW Jr 1981 Guanine nucleotides: key regulators of hormone receptor-adenylate cyclase interaction. Endocrine Rev 2:275

26. Stull JT, Mayer SE 1979 Biochemical mechanisms of adrenergic and cholinergic regulation of myocardial contractility. In Berne RM (ed) Handbook of Physiology, vol l, sect 2. American Physiological Society, Bethesda, MD, p 581

27. Tse J, Powell JR, Baste CA, Priest RE, Kuo JF 1979 Isoproterenol-induced cardiac hypertrophy: modifications in characteristics of $\beta$-adrenergic receptor, adenylate cyclase, and ventricular contraction. Endocrinology 105:246

28. Vapaavouri EK, Shinebourne EA, Williams RL, Heymann MA, Rudolph AM 1973 Development of cardiovascular responses to autonomic blockade in intact fetal and neonatal lambs. Biol Neonate 22:177

29. Ward RM Mirkin BL, Singh S, Daniels C 1981 Developmental increase in the cardiac chemotropic response to isoproterenol (IS). Pediatr Res 15:503

30. Whitsett JA, Darovec-Beckerman C 1981 Developmental aspects of $\beta$-adrenergic receptors and catecholamine-sensitive adenylate in rat myocardium. Pediatr Res 15:1363

\title{
Effects of Acidosis on Fetal and Maternal Blood Coagulation: A Fetal Lamb Model
}

\author{
C. THOMAS KISKER, DAVID P. BOHLKEN, AND WILLIAM R. CLARKE \\ Departments of Pediatrics and Preventive Medicine, University of Iowa College of Medicine, \\ Iowa City, Iowa 52242
}

\begin{abstract}
The effects of fetal acidosis (mean pH 6.93) on fetal and maternal blood coagulation were measured. Test results from 10 fetal lambs and mother ewes $(127 \pm$ 2 days mean gestation) before and after fetal lactic acid infusions were compared to test results from eight control fetal lambs and mother ewes (127 \pm 3 days mean gestation) before and after control glucose infusion. Significant changes found in acidotic fetal lambs not seen in control fetuses included an increase in the white blood cell count (mean $2800 / \mathrm{mm}^{3}$ before to $3600 / \mathrm{mm}^{3}$ after acidosis; $p=$ 0.0009 ), a shortening of the thrombin time (mean $17.8 \mathrm{~s}$ before to $11.2 \mathrm{~s}$ after acidosis; $p=0.0001$ ), and decreases in the activities of factor $\mathrm{V}$ (mean $57 \%$ before to $37 \%$ after acidosis; $p=0.0014$ ) and factor IX (mean $35 \%$ before to $29 \%$ after acidosis; $p=0.0128$ ). There was also a reduction in the concentration of fibrinogen (mean $147 \mathrm{mg} / 100 \mathrm{ml}$ before to $125 \mathrm{mg} / 100 \mathrm{ml}$ after acidosis; $p=0.0492$ ) but no significant changes in the levels of fibrin monomer, fibrin-
\end{abstract}

Received April 25, 1984; accepted July 27, 1984.

Address correspondence C. Thomas Kisker, M.D., Department of Pediatrics, University of lowa Hospitals and Clinics, Iowa City, IA 52242.

This research was supported by Grant R01 HD12574 from the National Institutes of Health. ogen/fibrin degradation products, or antithrombin III. In vitro exposure of five different fetal whole blood samples to a $\mathrm{pH}$ of 6.9 for $2 \mathrm{~h}$ at $37^{\circ} \mathrm{C}$ did not result in significant changes in any of the coagulation factor activities. A significant decrease in the level of factor $V$ was also found in the mother ewes of the acidotic fetuses (mean $141 \%$ before to $113 \%$ after acidosis; $p=0.006$ ) and a decrease in the level of maternal factor IX approached significance (mean $119 \%$ before to $102 \%$ after acidosis; $p=0.0564$ ). Two hours of severe fetal lactic acidosis induces changes in blood coagulation, but not the usual findings of disseminated intravascular coagulation. Corresponding decreases in factor $\mathrm{V}$ and $\mathrm{IX}$ activities in the mothers of acidotic fetal lambs suggest the liberation of a mediator capable of crossing the placenta and influencing maternal coagulation. (Pediatr Res 19: 78-82, 1985)

Significant acidosis is likely to occur in the fetus in association with placental infarction, cord compression, or partial abruption. Acidosis may also be present in association with hypoxia in 
newborns suffering from severe birth asphyxia or the respiratory distress syndrome. Previous studies in our laboratory indicated that hypoxia in the absence of acidosis did not result in intravascular coagulation in either early gestation or near-term fetal lambs $(10,11)$. Thus, we concluded that acidosis rather than hypoxia might be the trigger for the intravascular coagulation observed in stressed neonates with acidosis.

Acidosis is known to be associated with a shortening of the whole blood clotting time and disseminated intravascular coagulation $(4,7,13)$. Studies by Rivers and Hathaway (17) demonstrated that tissue factor coagulant activity developed in human newborn umbilical cord leukocytes when exposed to severe $\mathrm{pH}$ reduction by lactic or hydrochloric acid. Bishop et al. (3) observed decreased platelets and fibrinogen in pregnant ewes when thromboplastin was infused into exteriorized fetal lambs although neither thromboplastin nor other blood coagulation factors cross the placenta $(2,3,5,14)$. To examine the effects of fetal acidosis on fetal blood coagulation in utero and to assess the possibility of detecting changes in the maternal circulation, 10 chronically catheterized fetal lambs were subjected to $2 \mathrm{~h}$ of acidosis by infusing lactic acid intravenously. The studies were conducted in the absence of hypotension or hypoxia so that the isolated effects of acidosis in the intact fetus could be measured. Blood samples were obtained on both the fetuses and mother ewes before and after the $2 \mathrm{~h}$ of fetal acidosis. Results of coagulation measurements on the samples from this test group were compared with results on blood samples obtained on eight control fetal lambs and their mothers before and after glucose infusion.

\section{MATERIALS AND METHODS}

Pregnant mixed breed Dorset-Suffolk ewes were obtained from existing sources and were housed throughout the study at the University of Iowa Animal Quarters.

The gestational ages of the sheep fetuses were known based on induced ovulation techniques (1). Before surgery, the animals were fasted for $24 \mathrm{~h}$. Anesthesia of the ewe and surgery on the fetus were performed as described previously $(9,18)$. Under operating room conditions with sterile technique, polyethylene catheters (i.d., $0.86 \mathrm{~mm}$, and o.d., $1.27 \mathrm{~mm}$ ) to which heparin had been bound to both internal and external surfaces (CORMED, Inc., Middleport, NY) were inserted into the femoral artery and vein of the fetus and advanced to the aorta and inferior vena cava, respectively. A separate but nonheparinized catheter was also fixed to the fetal external abdominal wall to measure amniotic pressure. The catheters were brought out through a skin pouch to the side of the ewe and enclosed in a zip lock bag. After surgery, the ewe was kept in a restricted area and fed a standard diet. A minimum of 5 days for recovery was allowed before studies were done.

During the studies, the ewes with their chronically catheterized fetuses were transferred into small carts restricting them to upright positions. Acute catheters were then placed in the external jugular veins of the mother ewes to obtain maternal blood samples.

Fetal and maternal blood $(0.5 \mathrm{ml})$ was collected anaerobically in heparinized plastic syringes and measurements of $\mathrm{pH}, \mathrm{PCO}_{2}$, $\mathrm{PO}_{2}$ were immediately determined with the appropriate $\mathrm{pH}, \mathrm{PCO}_{2}$, $\mathrm{PO}_{2}$ electrodes at $39^{\circ} \mathrm{C}$ using a radiometer pH amp $72 \mathrm{NK} 2$ acid base analyzer (Radiometer America Inc., Dallas, TX). Hb, hematocrit, and white blood cell counts were measured using a Coulter Model S on $0.5-\mathrm{ml}$ aliquots of fetal and maternal blood that were anticoagulated with EDTA. Platelet counts were also obtained on these same aliquots using phase microscopy.

Coagulation factor activities were measured on fetal and maternal plasma from $2.7-\mathrm{ml}$ aliquots of blood anticoagulated with $0.3 \mathrm{ml}$ of $0.05 \mathrm{M}$ sodium citrate, $\mathrm{pH} 5.0$. Standard techniques for measuring the prothrombin times (19) and partial thromboplastin times (16) were used. Specific factor activities II, V, VII, VIII, IX, X, XI, and XII were measured using one-stage assays measuring the ability of test plasma to correct plasma known to be deficient in the factor to be tested (15). All activities measured are quoted as percents of a reference standard pool of sheep plasma obtained from 10 nonpregnant ewes. Plasma digestion products of fibrinogen/fibrin were measured in serum from a $0.5-\mathrm{ml}$ aliquot of blood allowed to clot in $5 \mu \mathrm{l}$ of a solution of $0.05 \mathrm{M}$ EACA, $0.125 \mathrm{M} \mathrm{CaCl}_{2}, 10 \mathrm{U} / \mathrm{ml}$ thrombin. The method of Mersky et al. (12) using a rabbit antisheep fibrinogen antibody and sheep fibrinogen coated red blood cells was used. Fibrin monomer was measured according to the method of Kisker (8) on plasma from $2.7-\mathrm{ml}$ aliquots of blood collected in $0.3 \mathrm{ml}$ of anticoagulant containing $2 \%$ EDTA, $10 \mathrm{mg} / \mathrm{ml}$ soybean trypsin inhibitor, 100 units/ml heparin $\mathrm{pH}$ 7.4. Sheep fibrinogen and antisheep fibrinogen antibody were used throughout.

Fetal arterial, venous, and amniotic pressures were recorded during the experiments using Stratham P23Db pressure transducers (Stratham Instruments, Oxnard, CA) and a beckman R611 recorder. Fetal heart rate was monitored with a cardiotachometer triggered from the fetal arterial pressure pulse.

To establish acidosis ( $\mathrm{pH}$ 6.9-7.0), the test fetal lambs were initially infused with $1.1 \mathrm{M}$ lactic acid in D5\% W at a rate of 0.6 $\mathrm{ml} / \mathrm{min}$ for $30 \mathrm{~min}$, after which the infusion rate was decreased to $0.42 \mathrm{ml} / \mathrm{min}$ for $2 \mathrm{~h}$, a rate which maintained the $\mathrm{pH}$ between 6.9 and 7.0. The eight control fetal lambs were infused at the same rates with dextrose $5 \%$ water for the same periods of time. Blood samples for measurement of blood coagulation factor activities and the other parameters described were obtained prior to and at the completion of the two hours of infusion.

The in vitro effect of exposure of fetal blood to lactic acidinduced acidosis was carried out by collecting blood from five fetal lambs in buffered $0.1 \mathrm{M} \mathrm{Na}$ citrate $\mathrm{pH} 7.4$. To $2.5-\mathrm{ml}$ aliquots of this blood, $4 \mu \mathrm{l}$ of $30 \%$ lactic acid or $5 \%$ dextrose was added. The addition of the lactic acid resulted in a decrease of the $\mathrm{pH}$ to $6.95 \pm 0.01$. The $\mathrm{pH}$ of the dextrose samples was 7.39 \pm 0.02 . Both aliquots were incubated at $37^{\circ} \mathrm{C}$ for $2 \mathrm{~h}$ prior to centrifuging for $30 \mathrm{~min}$ at $4^{\circ} \mathrm{C}$ to obtain platelet poor plasma. Coagulation tests on these plasmas were then done as described for the in vivo experiments.

Analysis of covariance measures were used to test for differences in test results before and after the in vivo infusions in the control and acidotic fetuses and ewes. The paired $t$ test was used to test for differences in the control and test samples exposed to lactic acid in vitro.

\section{RESULTS}

Baseline values and the values postinfusion for the acidotic fetal lambs, the control lambs, and their mother ewes for $\mathrm{Hb}$, hematocrit, white blood cell count, $\mathrm{PO}_{2}, \mathrm{PCO}_{2}, \mathrm{pH}$, and serum lactate are presented in Table 1 . There were no changes in the heart rate or mean arterial pressure in either control or acidotic fetal lambs. Changes specific to the acidotic fetal lambs included the decrease in $\mathrm{pH}$ during the period of acidosis from 7.37 to 6.95 ; an increase in the blood lactate level from $665-3044 \mathrm{pg} /$ $\mathrm{dl}$; and a slight but significant increase in the white blood cell count from $2800-3600 / \mathrm{mm}^{3}$. There was a slight although significant decrease in the hematocrit in both the acidotic and the control fetal lambs, thought to be the result of blood sampling during the experiments.

In Table 2 are presented the values pre- and postinfusion for the acidotic fetal lambs, the control lambs, and their mother ewes for the various coagulation parameters measured. Although there was not a significant change in the prothrombin time or the partial thromboplastin time in any of the animals, the thrombin time in the fetal lambs was shortened from 16.6 to $11.2 \mathrm{~s}$. No similar shortening was seen in the mothers of the acidotic fetal lambs. A small although significant decrease in the fibrinogen concentration was also seen in the fetal lambs exposed to acidosis $(159 \mathrm{mg} / 100 \mathrm{ml}$ before acidosis to $137 \mathrm{mg} / 100 \mathrm{ml}$ after acidosis). The greatest change in activity was seen in factor $\mathrm{V}$ 
Table 1. Results of in vivo exposure to lactic acid (mean \pm SD)

\begin{tabular}{|c|c|c|c|c|c|c|c|c|}
\hline & \multicolumn{4}{|c|}{ Fetus } & \multicolumn{4}{|c|}{ Ewe } \\
\hline & \multicolumn{2}{|c|}{$\begin{array}{l}\text { Acidotic } \\
(n=10)\end{array}$} & \multicolumn{2}{|c|}{$\begin{array}{l}\text { Control } \\
(n=8)\end{array}$} & \multicolumn{2}{|c|}{$\begin{array}{l}\text { Acidotic } \\
(n=10)\end{array}$} & \multicolumn{2}{|c|}{$\begin{array}{l}\text { Control } \\
(n=8)\end{array}$} \\
\hline & Pre & Post & Pre & Post & Pre & Post & Pre & Post \\
\hline $\mathrm{Hb}(\mathrm{g} / \mathrm{dl})$ & $\begin{array}{c}10.7 \\
( \pm 1.2)\end{array}$ & $\begin{array}{r}10.0 \\
( \pm 1.1)\end{array}$ & $\begin{array}{c}10.9 \\
( \pm 1.3)\end{array}$ & $\begin{array}{c}10.2 \\
( \pm 1.4)\end{array}$ & $\begin{array}{r}9.0 \\
( \pm 1.2)\end{array}$ & $\begin{array}{c}9.1 \\
( \pm 0.9)\end{array}$ & $\begin{array}{c}9.4 \\
( \pm 1.0)\end{array}$ & $\begin{array}{c}9.4 \\
( \pm 1.3)\end{array}$ \\
\hline Hematocrit & 32.7 & $\begin{array}{r}31.3 \\
(+36)\end{array}$ & 34.2 & $\begin{array}{c}31.6 \\
(+48)\end{array}$ & 26.7 & 25.6 & 28.1 & $\begin{array}{c}27.4 \\
(+37)\end{array}$ \\
\hline $\begin{array}{l}\text { White blood count } \\
\left(\mathrm{mm}^{3} \times 10^{3}\right)\end{array}$ & $\begin{array}{c}( \pm 3.5) \\
2.8 \\
( \pm 0.8)\end{array}$ & $\begin{array}{c}( \pm 3.6) \\
3.6^{*} \\
( \pm 1.7)\end{array}$ & $\begin{array}{c}( \pm 4.5) \\
3.3 \\
( \pm 1.7)\end{array}$ & $\begin{array}{c}( \pm 4.8) \\
2.6 \\
( \pm 1.6)\end{array}$ & $\begin{array}{c}7.8 \\
( \pm 2.1)\end{array}$ & $\begin{array}{c}(I 2 . J) \\
8.1 \\
( \pm 1.5)\end{array}$ & $\begin{array}{c}8.6 \\
( \pm 1.2)\end{array}$ & $\begin{array}{c}8.8 \\
( \pm 1.3)\end{array}$ \\
\hline $\mathrm{Po}_{2}(\mathrm{~mm} \mathrm{Hg})$ & $\begin{array}{c}21.3 \\
( \pm 4.2)\end{array}$ & $\begin{array}{r}25.8 \\
( \pm 3.5)\end{array}$ & $\begin{array}{c}17.4 \\
( \pm 6.2)\end{array}$ & $\begin{array}{c}21.2 \\
( \pm 7.1)\end{array}$ & $\begin{array}{c}52.5 \\
( \pm 10.2)\end{array}$ & $\begin{array}{c}48.4 \\
( \pm 10.9)\end{array}$ & $\begin{array}{c}48.6 \\
( \pm 10.1)\end{array}$ & $\begin{array}{l}45.5 \\
( \pm 10.2)\end{array}$ \\
\hline $\mathrm{PCO}_{2}(\mathrm{~mm} \mathrm{Hg})$ & $\begin{array}{c}48.6 \\
( \pm 7.6)\end{array}$ & $\begin{array}{r}52.2 \\
( \pm 8.2)\end{array}$ & $\begin{array}{c}46.4 \\
( \pm 4.0)\end{array}$ & $\begin{array}{c}47.3 \\
( \pm 5.5)\end{array}$ & $\begin{array}{c}33.3 \\
( \pm 8.2)\end{array}$ & $\begin{array}{c}35.5 \\
( \pm 6.7)\end{array}$ & $\begin{array}{c}33.2 \\
( \pm 3.0)\end{array}$ & $\begin{array}{c}41.6 \\
( \pm 10.3)\end{array}$ \\
\hline $\mathrm{pH}$ & $\begin{array}{c}7.37 \\
( \pm 0.04)\end{array}$ & $\begin{array}{c}6.95^{*} \\
( \pm 0.05)\end{array}$ & $\begin{array}{r}7.38 \\
( \pm 0.05)\end{array}$ & $\begin{array}{r}7.36 \\
( \pm 0.06)\end{array}$ & $\begin{array}{c}7.45 \\
( \pm 0.04)\end{array}$ & $\begin{array}{c}7.45 \\
( \pm 0.04)\end{array}$ & $\begin{array}{r}7.52 \\
( \pm 0.04)\end{array}$ & $\begin{array}{r}7.50 \\
( \pm 0.05)\end{array}$ \\
\hline $\begin{array}{l}\text { Lactate } \\
\qquad(\mathrm{pg} / \mathrm{dl})\end{array}$ & $\begin{array}{l}665 \\
( \pm 308\end{array}$ & $\begin{array}{l}3044^{*} \\
( \pm 670)\end{array}$ & $\begin{array}{l}623 \\
( \pm 445)\end{array}$ & $\begin{array}{l}859 \\
( \pm 780)\end{array}$ & $\begin{array}{l}363 \\
( \pm 212)\end{array}$ & $\begin{array}{l}315 \\
( \pm 72)\end{array}$ & $\begin{array}{l}376 \\
( \pm 94)\end{array}$ & $\begin{array}{l}284 \\
( \pm 117)\end{array}$ \\
\hline $\begin{array}{l}\text { Mean arterial pressure } \\
(\mathrm{mm} \mathrm{Hg})\end{array}$ & $\begin{array}{r}49.7 \\
( \pm 5.4)\end{array}$ & $\begin{array}{r}52.7 \\
( \pm 6.1)\end{array}$ & $\begin{array}{l}41 \\
( \pm 2.9)\end{array}$ & $\begin{array}{c}40 \\
( \pm 5.6)\end{array}$ & & & & \\
\hline $\begin{array}{l}\text { Heart rate } \\
\quad \text { (beats } / \mathrm{min} \text { ) }\end{array}$ & $\begin{array}{l}180 \\
( \pm 12)\end{array}$ & $\begin{array}{c}188 \\
( \pm 12)\end{array}$ & $\begin{array}{l}198 \\
( \pm 26)\end{array}$ & $\begin{array}{l}179 \\
( \pm 18)\end{array}$ & & & & \\
\hline
\end{tabular}

* Acidotic fetuses pre and post significantly different from controls (white blood cells, $p=0.0009 ; \mathrm{pH}, p=0.0001 ;$ lactate, $p=0.0001$ ).

Table 2. Results of in vivo exposure to lactic acid (mean $\pm S D)$

\begin{tabular}{|c|c|c|c|c|c|c|c|c|}
\hline & \multicolumn{4}{|c|}{ Fetus } & \multicolumn{4}{|c|}{ Ewe } \\
\hline & \multicolumn{2}{|c|}{$\begin{array}{l}\text { Acidotic } \\
(n=10)\end{array}$} & \multicolumn{2}{|c|}{$\begin{array}{l}\text { Control } \\
(n=8)\end{array}$} & \multicolumn{2}{|c|}{$\begin{array}{l}\text { Acidotic } \\
(n=10)\end{array}$} & \multicolumn{2}{|c|}{$\begin{array}{l}\text { Control } \\
(n=8)\end{array}$} \\
\hline & Pre & Post & Pre & Post & Pre & Post & Pre & Post \\
\hline $\mathrm{PT}(\mathrm{s})$ & $\begin{array}{c}17.1 \\
( \pm 1.7)\end{array}$ & $\begin{array}{c}18.4 \\
( \pm 2.3)\end{array}$ & $\begin{array}{c}16.9 \\
( \pm 1.6)\end{array}$ & $\begin{array}{c}17.3 \\
( \pm 2.0)\end{array}$ & $\begin{array}{c}13.6 \\
( \pm 1.7)\end{array}$ & $\begin{array}{c}13.1 \\
( \pm 1.1)\end{array}$ & $\begin{array}{c}14.0 \\
( \pm 1.1)\end{array}$ & $\begin{array}{c}13.5 \\
( \pm 0.9)\end{array}$ \\
\hline PTT (s) & $\begin{array}{c}47.3 \\
( \pm 11.3)\end{array}$ & $\begin{array}{c}47.1 \\
( \pm 13.3)\end{array}$ & $\begin{array}{r}44.5 \\
( \pm 8.3)\end{array}$ & $\begin{array}{c}45.9 \\
( \pm 9.3)\end{array}$ & $\begin{array}{c}30.2 \\
( \pm 6.5)\end{array}$ & $\begin{array}{c}33.1 \\
( \pm 6.3)\end{array}$ & $\begin{array}{c}42.6 \\
( \pm 9.0)\end{array}$ & $\begin{array}{c}35.9 \\
( \pm 8.6)\end{array}$ \\
\hline Thrombin time (s) & $\begin{array}{c}16.1 \\
( \pm 5.2)\end{array}$ & $\begin{array}{r}11.2^{*} \\
( \pm 1.7)\end{array}$ & $\begin{array}{c}18.3 \\
( \pm 5.4)\end{array}$ & $\begin{array}{c}19.1 \\
( \pm 6.5)\end{array}$ & $\begin{array}{c}14.7 \\
( \pm 2.9)\end{array}$ & $\begin{array}{c}13.9 \\
( \pm 3.3)\end{array}$ & $\begin{array}{c}16.7 \\
( \pm 1.9)\end{array}$ & $\begin{array}{c}16.1 \\
( \pm 2.9)\end{array}$ \\
\hline $\begin{array}{l}\text { Fibrinogen } \\
\quad(\mathrm{mg} / 100 \mathrm{ml})\end{array}$ & $\begin{array}{l}159 \\
( \pm 81)\end{array}$ & $\begin{array}{l}137^{*} \\
( \pm 58)\end{array}$ & $\begin{array}{l}120 \\
( \pm 38)\end{array}$ & $\begin{array}{l}124 \\
( \pm 41)\end{array}$ & $\begin{array}{l}305 \\
( \pm 105)\end{array}$ & $\begin{array}{l}313 \\
( \pm 48)\end{array}$ & $\begin{array}{l}364 \\
( \pm 64)\end{array}$ & $\begin{array}{l}367 \\
( \pm 60)\end{array}$ \\
\hline $\begin{array}{l}\text { Factor II activity } \\
\text { (\% of adult) }\end{array}$ & $\begin{array}{c}44 \\
( \pm 9)\end{array}$ & $\begin{array}{c}39 \\
( \pm 4)\end{array}$ & $\begin{array}{c}39 \\
( \pm 9)\end{array}$ & $\begin{array}{c}40 \\
( \pm 7)\end{array}$ & $\begin{array}{l}148 \\
( \pm 72)\end{array}$ & $\begin{array}{l}142 \\
( \pm 85)\end{array}$ & $\begin{array}{c}99 \\
( \pm 23)\end{array}$ & $\begin{array}{l}107 \\
( \pm 19)\end{array}$ \\
\hline $\begin{array}{l}\text { Factor } V \text { activity } \\
\text { (\% of adult) }\end{array}$ & $\begin{array}{c}59 \\
( \pm 33)\end{array}$ & $\begin{array}{c}38^{*} \\
( \pm 27)\end{array}$ & $\begin{array}{c}55 \\
( \pm 20)\end{array}$ & $\begin{array}{c}55 \\
( \pm 23)\end{array}$ & $\begin{array}{l}137 \\
( \pm 47)\end{array}$ & $\begin{array}{l}116^{*} \\
( \pm 22)\end{array}$ & $\begin{array}{l}112 \\
( \pm 44)\end{array}$ & $\begin{array}{l}126 \\
( \pm 49)\end{array}$ \\
\hline $\begin{array}{l}\text { Factor VII activity } \\
\text { (\% of adult })\end{array}$ & $\begin{array}{c}48 \\
( \pm 21)\end{array}$ & $\begin{array}{c}44 \\
( \pm 18)\end{array}$ & $\begin{array}{c}52 \\
( \pm 21)\end{array}$ & $\begin{array}{c}55 \\
( \pm 19)\end{array}$ & $\begin{array}{l}153 \\
( \pm 60)\end{array}$ & $\begin{array}{l}142 \\
( \pm 35)\end{array}$ & $\begin{array}{l}125 \\
( \pm 24)\end{array}$ & $\begin{array}{l}127 \\
( \pm 23)\end{array}$ \\
\hline $\begin{array}{l}\text { Factor VIII activity } \\
\text { (\% of adult) }\end{array}$ & $\begin{array}{l}34 \\
( \pm 13)\end{array}$ & $\begin{array}{c}28 \\
( \pm 13)\end{array}$ & $\begin{array}{l}29 \\
( \pm 10)\end{array}$ & $\begin{array}{c}29 \\
( \pm 12)\end{array}$ & $\begin{array}{l}129 \\
( \pm 47)\end{array}$ & $\begin{array}{l}113 \\
( \pm 27)\end{array}$ & $\begin{array}{l}85 \\
( \pm 25)\end{array}$ & $\begin{array}{l}103 \\
( \pm 22)\end{array}$ \\
\hline $\begin{array}{l}\text { Factor IX activity } \\
\text { (\% of adult) }\end{array}$ & $\begin{array}{c}33 \\
( \pm 12)\end{array}$ & $\begin{array}{c}27^{*} \\
( \pm 9)\end{array}$ & $\begin{array}{c}39 \\
( \pm 23)\end{array}$ & $\begin{array}{c}37 \\
( \pm 18)\end{array}$ & $\begin{array}{l}113 \\
( \pm 33)\end{array}$ & $\begin{array}{l}103 \\
( \pm 22)\end{array}$ & $\begin{array}{l}111 \\
( \pm 22)\end{array}$ & $\begin{array}{l}118 \\
( \pm 24)\end{array}$ \\
\hline $\begin{array}{l}\text { Factor X activity } \\
\text { (\% of adult) }\end{array}$ & $\begin{array}{l}36 \\
( \pm 15)\end{array}$ & $\begin{array}{c}29 \\
( \pm 13)\end{array}$ & $\begin{array}{c}37 \\
( \pm 23)\end{array}$ & $\begin{array}{c}38 \\
( \pm 21)\end{array}$ & $\begin{array}{l}117 \\
( \pm 16)\end{array}$ & $\begin{array}{l}112 \\
( \pm 21)\end{array}$ & $\begin{array}{l}107 \\
( \pm 16)\end{array}$ & $\begin{array}{l}105 \\
( \pm 14)\end{array}$ \\
\hline $\begin{array}{l}\text { Factor XI activity } \\
\text { (\% of adult) }\end{array}$ & $\begin{array}{c}40 \\
( \pm 23)\end{array}$ & $\begin{array}{c}32 \\
( \pm 19)\end{array}$ & $\begin{array}{c}51 \\
( \pm 20)\end{array}$ & $\begin{array}{c}47 \\
( \pm 20)\end{array}$ & $\begin{array}{l}163 \\
( \pm 80)\end{array}$ & $\begin{array}{l}138 \\
( \pm 51)\end{array}$ & $\begin{array}{l}104 \\
( \pm 29)\end{array}$ & $\begin{array}{l}135 \\
( \pm 46)\end{array}$ \\
\hline $\begin{array}{l}\text { Factor XII activity } \\
\text { (\% of adult) }\end{array}$ & $\begin{array}{c}42 \\
( \pm 14)\end{array}$ & $\begin{array}{c}39 \\
( \pm 22)\end{array}$ & $\begin{array}{c}35 \\
( \pm 13)\end{array}$ & $\begin{array}{c}39 \\
( \pm 18)\end{array}$ & $\begin{array}{l}119 \\
( \pm 43)\end{array}$ & $\begin{array}{l}108 \\
( \pm 23)\end{array}$ & $\begin{array}{c}83 \\
( \pm 19)\end{array}$ & $\begin{array}{l}107 \\
( \pm 33)\end{array}$ \\
\hline $\begin{array}{l}\text { Fibrin monomer } \\
(\mathrm{g} / \mathrm{ml})\end{array}$ & $\begin{array}{r}4.4 \\
( \pm 3.2)\end{array}$ & $\begin{array}{r}6.3 \\
( \pm 5.9)\end{array}$ & $\begin{array}{c}5.9 \\
( \pm 4.0)\end{array}$ & $\begin{array}{r}6.8 \\
( \pm 3.3)\end{array}$ & $\begin{array}{r}9.6 \\
( \pm 5.6)\end{array}$ & $\begin{array}{c}9.4 \\
( \pm 4.6)\end{array}$ & $\begin{array}{r}9.1 \\
( \pm 5.0)\end{array}$ & $\begin{array}{l}15.6^{*} \\
( \pm 8.9)\end{array}$ \\
\hline $\begin{array}{l}\text { Antithrombin III } \\
\text { (\% of adult) }\end{array}$ & $\begin{array}{l}100 \\
( \pm 19)\end{array}$ & $\begin{array}{l}95 \\
( \pm 21)\end{array}$ & $\begin{array}{l}103 \\
( \pm 25)\end{array}$ & $\begin{array}{l}104 \\
( \pm 27)\end{array}$ & $\begin{array}{c}92 \\
( \pm 21)\end{array}$ & $\begin{array}{c}92 \\
( \pm 31)\end{array}$ & $\begin{array}{l}100 \\
( \pm 43)\end{array}$ & $\begin{array}{c}94 \\
( \pm 33)\end{array}$ \\
\hline $\begin{array}{l}\text { Platelets } \\
\quad\left(\mathrm{mm}^{3} \times 10^{3}\right)\end{array}$ & $\begin{array}{l}301 \\
( \pm 144)\end{array}$ & $\begin{array}{l}259 \\
( \pm 103)\end{array}$ & $\begin{array}{l}235 \\
( \pm 120)\end{array}$ & $\begin{array}{l}212 \\
( \pm 107)\end{array}$ & $\begin{array}{l}424 \\
( \pm 217)\end{array}$ & $\begin{array}{l}470 \\
( \pm 89)\end{array}$ & $\begin{array}{l}488 \\
( \pm 169)\end{array}$ & $\begin{array}{l}486 \\
( \pm 205)\end{array}$ \\
\hline
\end{tabular}

* Acidotic Pre and Post significantly different (fetal thrombin time, $p=0.0001$; fetal fibrinogen, $p=0.0492$; fetal factor V, $p=0.0014$; fetal factor IX, $p=0.0128$; ewe factor $\mathrm{V}, p=0.0066$; control ewe fibrin monomer, $p=0.0390$ ). 
levels from acidotic fetal lambs. Factor $\mathrm{V}$ decreased from $59 \%$ before acidosis to $38 \%$ after acidosis. Of interest, the factor $\mathrm{V}$ levels in the mother ewes also showed a significant decrease in activity from 137 to $116 \%$. Factor IX activity decreased significantly in the acidotic fetal lambs from a level of $33 \%$ to a level of $27 \%$. There was also a decrease in the factor IX activity in the ewes of the acidotic fetal lambs from 129 to $113 \%$ which approached significance $(p=0.0564)$. None of the other clotting factor activities including antithrombin III and fibrin monomer showed significant changes in either group of fetal lambs. There was an increase in the level of fibrin monomer in the control mother ewes from 9.1 to $15.6 \mu \mathrm{g} / \mathrm{ml}$ which is unexplained although probably the result of fibrin formation during sample collection from some of these ewes. Fibrinogen/fibrin degradation products were also measured on all animals, but none exceeded the normal $8 \mu \mathrm{g} / \mathrm{dl}$ and are therefore not reported in Table 2.

In Table 3 are presented the results of exposure of fetal blood to lactic acid in vitro. The in vitro exposure of fetal blood to $2 \mathrm{~h}$ of acidosis ( $\mathrm{pH} 6.96)$ at $37^{\circ} \mathrm{C}$ did not result in any changes of blood coagulation factor activities.

\section{DISCUSSION}

Crowell and Houston (6) first demontrated that lowering the $\mathrm{pH}$ of blood to 6.5 in vitro and in vivo led to a marked shortening of the whole blood clotting time, even in the presence of heparin. They also observed that when lactic acid was injected into an arterial venous shunt, the animals died much more rapidly than when it was given interarterially at the same rate where rapid mixing occurred. Hardaway et al. (7) demonstrated a significant shortening of the whole blood clotting time in heparinized blood when the $\mathrm{pH}$ was reduced with lactic acid to 7.1 or below. Their results suggested that heparin was not an effective anticoagulant at acid $\mathrm{pH}$. Hardaway's studies further demonstrated that a combination of acidosis and hypotension could initiate disseminated intravascular coagulation in experimental dogs. Broersma et al. (4) were also able to initiate intravascular coagulation in dogs by infusing lactic acid. Their studies indicated that a $\mathrm{pH}$ of

Table 3. In vitro exposure of fetal blood to lactic acid $(n=5$; mean $\pm S D$

\begin{tabular}{lcc}
\hline & $\begin{array}{c}\text { Before lactic } \\
\text { acid }\end{array}$ & $\begin{array}{c}\text { After lactic } \\
\text { acid }\end{array}$ \\
\hline Pro time (s) & 17.5 & 17.3 \\
& $( \pm 1.9)$ & $( \pm 1.48)$ \\
PTT (s) & 60.1 & 61.8 \\
& $( \pm 14.5)$ & $( \pm 16.1)$ \\
Thrombin time (s) & 16.2 & 14.9 \\
& $( \pm 1.9)$ & $( \pm 1.4)$ \\
Fibrinogen & 123.1 & 118.6 \\
(mg/100 ml) & $( \pm 32.8)$ & $( \pm 28)$ \\
Factor II activity & 31.0 & 30.3 \\
(\% of adult) & $( \pm 5.2)$ & $( \pm 2.8)$ \\
Factor V activity & 46.5 & 46.2 \\
(\% of adult) & $( \pm 6.9)$ & $( \pm 5.9)$ \\
Factor VII activity & 44.1 & 42.9 \\
(\% of adult) & $( \pm 6.3)$ & $( \pm 8.5)$ \\
Factor VIII activity & 37.4 & 37.1 \\
(\% of adult) & $( \pm 16.5)$ & $( \pm 14.9)$ \\
Factor IX activity & 24.7 & 25.7 \\
(\% of adult) & $( \pm 7.2)$ & $( \pm 7.7)$ \\
Factor X activity & 27.5 & 28.6 \\
(\% of adult) & $( \pm 5.9)$ & $( \pm 9.4)$ \\
Factor XI activity & 36.3 & 37.2 \\
(\% of adult) & $( \pm 6.5)$ & $( \pm 10.1)$ \\
Factor XII activity & 42.7 & 41.6 \\
(\% of adult) & $( \pm 9.4)$ & $( \pm 7.3)$ \\
\hline
\end{tabular}

below 7.2 was the "trigger" for intravascular coagulation. As the $\mathrm{pH}$ dropped, the heart rate fell, the platelet count progressively decreased, and although the blood clotting time initially shortened it eventually became prolonged. Within $2 \mathrm{~h}$ there were significant decreased in the platelet count as well as in the levels of fibrinogen, prothrombin, factor V, and factor VIII.

Nagasue et al. (13) infused lactic acid into the superior mesenteric artery of dogs to establish a mean $\mathrm{pH}$ of 6.9 and were also able to initiate intravascular coagulation as indicated by decreased platelet counts, fibrinogen concentrations, and increased prothrombin times. All of these studies, done in adult animals, clearly established a relationship between acidosis and intravascular coagulation.

Studies by Rivers and Hathaway (17) on the production of tissue factor by leukocytes from the human umbilical cord blood indicated that exposing newborn leukocytes to severe reductions of $\mathrm{pH}$ ( 6.75 or below) resulted in the liberation of tissue factor, a potent initiator of blood coagulation. In order to study the effects of acidosis on the immature hemostatic mechanism, 10 fetal lambs of approximately 127 days gestation were rendered acidotic ( $\mathrm{pH}$ 6.95) for $2 \mathrm{~h}$ by infusing lactic acid intravenously.

Despite the severe reduction of $\mathrm{pH}$ in the fetal lambs (mean 6.95 ), the changes in coagulation factor activities were relatively minor and not in a range that would be clinically significant. The thrombin time shortened from 16.1 to $11.2 \mathrm{~s}$, suggesting a "hypercoagulable state." There was a slight decrease in fibrinogen concentration from 159 to $137 \mathrm{mg} / 100 \mathrm{ml}$. Similar decreases in factor V from 59 to $38 \%$, and factor IX from 33 to $27 \%$, were also found. Of interest, evidence for the initiation of intravascular coagulation was not found. Specifically, there was no generation of fibrin monomer or fibrin split products, nor were there significant reductions in antithrombin III levels, platelet counts, or factor VIII activities. In our studies, fetal acidosis was examined without associated hypotension or hypoxia. The initiation of disseminated intravascular coagulation by acidosis in the previous studies by Hardaway, Broersma, and Nagasue differ in that their animals were also hypotensive. It is probable that increased stasis associated with hypotension is necessary in addition to acidosis for the initiation of intravascular coagulation.

The precise mechanism whereby acidosis induces a shortening of the thrombin time, decreases in fibrinogen, factor $\mathrm{V}$, and factor IX activities is not clear. We could not demonstrate similar alterations by reducing the $\mathrm{pH}$ of fetal whole blood to 6.9 with the in vitro addition of lactic acid. This reduction in $\mathrm{pH}$ corresponded to that achieved in our fetal lambs but was not as low as the pH 6.5 used by Crowell and Houston or the pH 6.75 used by Rivers and Hathaway in their in vitro studies. The lack of change in our in vitro experiments suggest that the changes observed in the intact fetal lambs are not simply related to structural changes in the factors induced by an acid environment. Furthermore, changes in the rates of synthesis and/or degradation of the factors as a direct effect of lactic acidosis are unlikely explanations as decreases in factor $\mathrm{V}$ and factor IX activities were also apparent in mother ewes who were not acidotic or had increased blood lactate levels. Rather, the results suggest the liberation of a mediator generated during lactic acidosis which is capable of crossing the placenta.

Bishop et al. (3), in experiments on fetal lambs, found administering tissue thromboplastin to either the mother ewe or to the fetus resulted in the development of intravascular coagulation in both mother and fetus. They were not able to identify the factor or factors that crossed the placenta, although they did demonstrate that the transfer was not due to fibrin or fibrinogen breakdown products or to the infused thromboplastin. Their animals showed significant decreased in fibrinogen and factor $\mathrm{V}$. Factor IX activity levels were not presented in their report.

In summary, our studies indicate that a 2 -h period of severe acidosis (mean pH 6.93) in the fetal lamb results in a slight although significant change in some of the blood coagulation 
factor activities in both the fetal lamb and in the mother ewe. The changes were not consistent with classical disseminated intravascular coagulation. An additional stress such as hypotension is probably required to induce intravascular coagulation in the fetus. The exact mechanism responsible for the observed changes remains unclear. The changes are not related to mere exposure of fetal blood to a lowered $\mathrm{pH}$. The observation that the mother ewes also experience a reduction in factor $\mathrm{V}$ and factor IX activity in the absence of lactic acidosis suggests the liberation of a mediator from the fetus capable of crossing the placenta. These observations support the original findings of Bishop et al. (3) which also suggested the liberation of a factor or factors capable of crossing the placenta and influencing coagulation activity in both fetal and maternal blood.

\section{REFERENCES}

1. Ainsworth L, Hackett A, Heaney D, Longford G, Peters H 1977 Management of Reproduction in Sheep and Goats. A multi-disciplinary approach to the development of controlled breeding and intensive production systems for sheep. University of Wisconsin Press, Madison, WI, July 24

2. Biland L, Duckert F 1973 Coagulation factors of the newborn and his mother. Thromb Diath Haemorrh 29:644

3. Bishop AJ, Israelis LG, Chernick V, Israels ED 1971 Placental transfer of intravascular coagulation between mother and child. Pediatr Res 5:113

4. Broersma RJ, Bullemer GD, Mammen EF 1969. Blood coagulation changes in hemorrhagic shock and acidosis. Thromb Diath Haemorrh 36(suppl): 171

5. Cade JF, Hirsh J, Martin M 1969 Placental barrier to coagulation factors: Its relevance to the coagulation defect at birth and to haemorrhage in the newborn. Br Med J 2:281
6. Crowell JW, Houston B 1961 Effect of acidity on blood coagulation. Am J Physiol 201:379

7. Hardaway RM, Elovitz MJ, Brewster WR, Houchen DN 1964 Clotting time of heparinized blood-influence of acidosis. Arch Surg 89:701

8. Kisker CT 1979 Detection of fibrin monomer. J Clin Pathol 72:405

9. Kisker CT, Robillard JE, Clarke WR 1981 Development of blood coagulation-a fetal lamb model. Pediatr Res 15:1045

10. Kisker CT, Robillard JE, Clarke WR 1982 Blood coagulation changes after hypoxemia: a fetal lamb model. Pediatr Res 16:8

11. Kisker CT, Robillard JE, Clarke WR 1982 Blood coagulation changes following hypoxemia in the near term fetal lamb. Pediatr Res 16:732

12. Merskey C, Lalezari P, Johnson A A rapid simple sensitive method for measuring fibrinolytic slip products in human serum. Proc Soc Exp Biol Med 131:871

13. Nagasue N, Iwaki A, Yakaya H, Koyanagi N, Kobayashi M, Inokuchi K 1977 Disseminated intravascular coagulation and refractory shock induced by splanchnic metabolic acidosis. Surg Gynecol Obstet 144:519

14. Nossel HL, Lanzkowsky P, Levy S, Mibashan RS, Hansen JD 1966 A study of coagulation factor levels in women during labor and in their newborn infants. Thromb Diath Haemorrh 16:185

15. Owen CA, Bowie E, Didisheim P 1966 Test of hemostasis and blood coagulation. In: Cawley LP (ed) The Diagnosis of Bleeding Disorders. Little, Brown \& Co., Boston, pp 101-107

16. Proctor RR, Rapaport S 1961 The partial thromboplastin time with kaolin: simple screening test for first stage plasma clotting factor deficiencies. Am Clin Pathol 36:212

17. Rivers RPA, Hathaway WE 1975 Studies on tissue factor activity and production by leukocytes of human umbilical cord and adult origin. Pediatr Res 9:167

18. Robillard JE, Matson J, Sessions C, Smith F: Developmental aspects of renal tubular reabsorption of water in the lamb fetus. Pediatr Res 13:1172

19. Cartwright GE 1968 Prothrombin time. In: Cartwright GE (ed) Diagnostic Laboratory Hematology. Grune and Stratton, Inc, New York, pp 373-377

\section{Pituitary-Gonadal Function in Klinefelter Syndrome before and during Puberty}

JAMES A. SALBENBLATT, BRUCE G. BENDER, MARY H. PUCK, ARTHUR ROBINSON, CHARLES FAIMAN, AND JEREMY S. D. WINTER

National Jewish Hospital and Research Center/National Asthma Center; Departments of Pediatrics, Psychiatry, and Biochemistry, Biophysics and Genetics, University of Colorado School of Medicine, Denver, Colorado

[J.A.S., B.G.B., M.H.P., A.R.]; and the Departments of Paediatrics, Medicine and Physiology, University of Manitoba, Winnipeg, Manitoba, Canada [C.F., J.S.D.W.]

\begin{abstract}
Serum concentrations of follicle-stimulating hormone, luteinizing hormone, testosterone, and estradiol were determined at intervals before and during puberty in 40 individuals with Klinefelter syndrome $(47, \mathrm{XXY}$ karyotype), of whom 27 had been detected in neonatal cytogenetic screening programs. Prior to the appearance of sec-
\end{abstract}

Received March 12, 1984; accepted July 27, 1984.

Address for correspondence Arthur Robinson, M.D., National Jewish Hospital and Research Center, 3800 East Colfax Avenue, Denver, CO 80206.

This work was supported by U.S. Public Health Services Grant 5R01-HD10032; Grant RR-69 from the General Clinical Research Centers Program of the Division of Research Resources, National Institutes of Health; The Genetic Foundation; and The Children's Hospital of Winnipeg Research Foundation.

Presented in part at the Western Society for Pediatric Research, 1984.

Following the submission of this manuscript, one pubertal aneuploid subject has been found to have a low percent mosaicism with karyotype 46,XY/46,XX/ $47, \mathrm{XXY}(6: 13: 175)$ in blood and fibroblasts. ondary sexual changes, basal serum hormone concentrations and acute responses to stimulation with gonadotropinreleasing hormone and human chorionic gonadotropin were normal. The timing of the onset of clinical puberty was normal. Early pubertal boys showed initial testicular growth and normal serum testosterone levels, while serum follicle-stimulating hormone and estradiol concentrations were significantly elevated. By midpuberty, the Klinefelter subjects were uniformly hypergonadotropic and their testicular growth had ceased. Serum testosterone concentrations after age 15 remained in the low-normal adult range. Serum estradiol levels remained high, irrespective of the presence or absence of gynecomastia. Exaggerated responses to gonadotropin-releasing hormone are seen in pubertal subjects with elevated basal gonadotropin values. (Pediatr Res 19: 82-86, 1985) 